\title{
Analisis Fraksi Volume Bahan Bakar Uranium Karbida Pada Reaktor Cepat Berpendingin Gas Menggunakan SRAC Code
}

\author{
Ratna Dewi Syarifah ${ }^{* 1}$, Nabil Nabhan $\mathrm{MH}^{2}$, Zein Hanifah ${ }^{3}$, Iklimatul Karomah ${ }^{4}$, Ahmad Muzaki \\ Mabruri $^{5}$ dan Artoto Arkundato ${ }^{6}$ \\ 1,2,3,4,5,6 Jurusan Fisika, Fakultas Matematika dan Ilmu Pengetahuan Alam, Jalan Kalimantan No 37 \\ Jember 68121, Indonesia \\ e-mail: *11 rdsyarifah.fmipa@unej.ac.id, ${ }^{2}$ nabilnabhanmh41@gmail.com, ${ }^{3}$ han.berbagi@ gmail.com \\ 4karomahiklimatul@gmail.com, ${ }^{5}$ amuzaki073@gmail.com, ${ }^{6}$ a.arkundato@unej.ac.id
}

\begin{abstract}
The fuel volume fraction analysis has been carried out with uranium carbide in GasCooled Fast Reactor using the SRAC Code (Standard Reactor Analysis Code). This code was developed by the Japan Atomic Energy Agency (JAEA) and uses the latest nuclear data library JENDL 4.0. There are two calculation has been used, fuel pin cell calculation (PIJ Calculation) and core calculation (CITATION Calculation). In core calculation, the leakage is calculated so the calculation more precise. The CITATION calculation use two type of core configuration, i.e. homogeneous core configuration and heterogeneous core configuration. The power density value of two type core configuration is quite difference. It is better use heterogeneous core configuration than homogeneous core configuration, because the power density of heterogeneous core configuration is flatter than the other. The optimum design based on the analysis that has been carried out is the fuel volume fraction of $49 \%$ with a heterogeneous core configuration of 3 types of fuel percentages, for Fuel type $1=$ $9 \%$, Fuel type $2=12 \%$ and Fuel type $3=15 \%$ with the reactor is cylindrical and has a core diameter of $240 \mathrm{~cm}$ and a core height of $100 \mathrm{~cm}$.
\end{abstract}

Keywords : GFR, uranium carbide, SRAC Code, JENDL 4.0

\section{PENDAHULUAN}

The Generation IV International Forum atau disingkat GIF merupakan forum internasional resmi yang membahas tentang penelitian dan pengembangan reaktor Generasi ke IV. GIF mulai berdiri pada tahun 2002.
Setiap dua tahun sekali GIF Research and Development melakukan pertemuan rutin yang menghasilkan handbook yang berisi perkembangan reaktor Generasi ke IV. Reaktor Generasi ke IV mempunyai beberapa kelebihan yaitu aspek inheren safety (keselamatan melekat), sustainability (umur operasi yang panjang), non-proliferasi (limbahnya tidak bisa dijadikan senjata nuklir), dan lebih ekonomis dibandingkan dengan pembangkit listrik lainnya. Selain itu, reaktor Generasi IV juga mengembangkan sistem keselamatan pasif (passive safety) yang dapat meminimalkan kerja operator atau tanpa bergantung sepenuhnya pada operator (GIF, 2012).

Reaktor Generasi IV terdiri dari enam tipe reaktor, yaitu Reaktor Cepat Berpendingin Gas (Gas-Cooled Fast Reactor / GFR), Reaktor Cepat Berpendingin Timbal (Lead Cooled Fast Reactor / LFR), Reaktor Berpendingin Garam Cair (Molten Salt Reactor / MSR), Reaktor Berpendingin Sodium (Sodium Cooled Fast Reaktor / SFR), Reaktor Air Superkritis (Supercritical Water Cooled Reaktor / SCWR), dan Reaktor Bertekanan Tinggi (Very High Temperature Reaktor / VHTR) (GIF, 2002).

Topik penelitian tentang GFR saat ini sangat digemari. Beberapa penyebabnya adalah karena reaktor ini mampu bertahan pada suhu tinggi karena mengunakan pendingin gas yang hanya memiliki satu fasa , berdaya saing ekonomi, yaitu dengan kesederhanaan desain, lebih kompak dan lebih efisiensi. Serta memiliki demonstrasi keselamatan yang kuat, berdasarkan penilaian probabilitas keselamatan dan pertahanan dalam prinsip mendalam dan 
Ratna Dewi Syarifah, Nabil Nabhan MH, Zein Hanifah, Iklimatul Karomah, Ahmad Muzaki Mabruri dan Artoto Arkundato

Submitted: 21/10/2020; Revised: 14/12/2020; Accepted: 07/01/2021; Published: 30/04/2021

termasuk sistem manajemen kecelakaan yang parah (Anzieu et al., 2009).

Penelitian-penelitian tentang GFR sudah banyak dilakukan sebelumnya. Beberapa penelitian tentang GFR menggunakan bahan bakar uranium plutonium nitrida dan menggunakan kode SRAC (Syarifah et al., 2016; Syarifah et al., 2016; Syarifah et al., 2016; Syarifah et al., 2017; Syarifah et al., 2017; Syarifah et al., 2017; Syarifah et al., 2018; Syarifah et al., 2020; Syarifah et al., 2020). Pada penelitian-penelitian tersebut didapatkan hasil bahwa GFR mampu bertahan selama 20 tahun tanpa pengisian ulang bahan bakar dengan nilai excess reactivity dibawah $2 \%$. Nilai excess reactivity sangat penting dicari untuk mengetahui kekritisan reaktor. Pada analisis neutronik reaktor, kestabilan reaktor ditentukan oleh nilai kekritisan reaktor. Apabila reaktor dalam keadaan kritis, berarti reaktor tersebut dalam keadaan stabil.

Pada penelitian ini dilakukan analisis terhadap jenis bahan bakar uranium karbida (UC) pada reaktor cepat berpendingin gas. Analisisnya meliputi : analisis perbandingan persentase U-235 di dalam bahan bakar, analisis konfigurasi teras homogen dan heterogen, analisis fraksi volume bahan bakar dengan menggunakan code SRAC.

\section{METODE PENELITIAN}

Pada penelitian ini perhitungan yang dilakukan menggunakan SRAC Code. SRAC merupakan singkatan dari Standard Reactor Analysis Code. Code ini dikembangkan oleh Japan Atomic Energy Agency (JAEA) (Okumura, K., 2002). Penelitian ini menggunakan pustaka data nuklir Japanese Evaluated Nuclear Data Library versi 4.0 (JENDL 4.0), suatu database nuklir terbaru yang dikembangkan Jepang.

SRAC Code dioperasikan pada sistem operasi Linux. SRAC Code memiliki dua kali perhitungan, yang pertama adalah perhitungan sel bahan bakar (perhitungan PIJ) dan yang kedua alah perhitungan teras (perhitungan CITATION). Pada perhitungan PIJ, kita menghitung sel bahan bakar yang berbentuk sel heksagonal dengan metode Collision Probability Methods (CPM). Pada perhitungan sel bahan bakar, kebocoran neutron belum dipertimbangkan, tetapi pada perhitungan teras bahan bakar (CITATION), kebocoran neutron keluar dari teras sudah dihitung pada kode CITATION.

Gambar 1 merupakan geometri sel bahan bakar berbentuk heksagonal. Pada tengah sel bahan bakar terdapat bahan bakar, pada penelitian ini menggunakan uranium karbida. Setelah bahan bakar, ada selongsong (cladding) memakai silikon karbida dan pendingin (coolant) menggunakan gas helium. Silikon karbida mempunyai kelebihan memiliki titik lebur yang tinggi. Sehingga apabila terjadi kecelakaan reaktor yang terjadi karena tingginya temperatur, silicon carbide mampu bertahan untuk tidak meleleh.

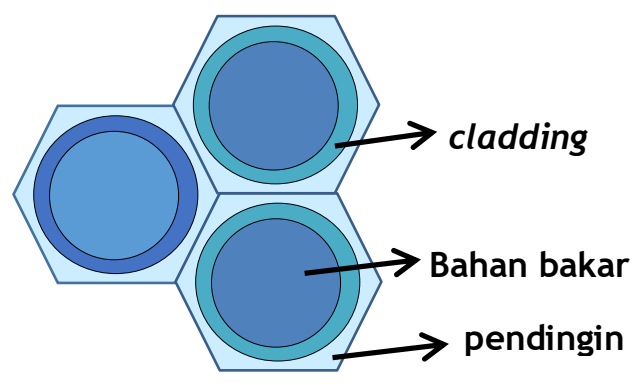

Gambar 1 Heksagonal sel

Setelah menghitung sel bahan bakar, maka diikuti dengan menghitung perhitungan teras reaktor dengan menggunakan CITATION. Perhitungan CITATION menggunakan konfigurasi teras homogen dan heterogen. Konfigurasi teras homogen terdiri dari satu tipe presentase bahan bakar dan konfigurasi teras heterogen terdiri dari beberapa tipe presentase bahan bakar. Pada penelitian ini konfigurasi teras heterogen terdiri dari tiga tipe bahan bakar. Pada Gambar 2 menunjukkan konfigurasi teras heterogen dengan tiga tipe presentase bahan bakar.

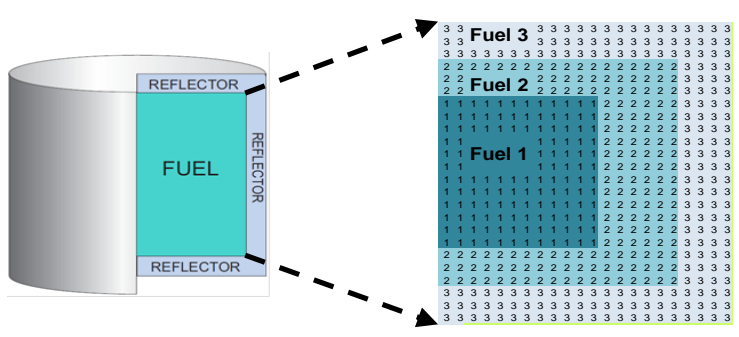

Gambar 2 Konfigurasi teras heterogen dengan tipe bahan bakar

Bahan bakar pertama (Fuel 1) berada pada tengah teras, seperti ditunjukkan pada 
Gambar 2. Fuel 2 berada diantara Fuel 1 dan Fuel 3, dan kemudian paling pinggir terdapat Fuel 3. Pada Tabel 1 dijelaskan mengenai spesifikasi desain reaktor cepat berpendingin gas yang diteliti. Fraksi volume bahan bakar dan pendingin di variasi seperti yang ada pada tabel. Sedangkan fraksi volume cladding dibuat tetap yaitu $10 \%$.

Tabel 1 Parameter desain dari Reaktor GFR $300 \mathrm{MW}$ th

\begin{tabular}{ll}
\hline Parameter desain & Spesifikasi \\
\hline Bahan Bakar & $\begin{array}{l}\text { Uranium Karbida } \\
\text { (UC) }\end{array}$ \\
\hline Cladding (selongsong) & $\begin{array}{l}\text { Silikon Karbida } \\
\text { (SiC) }\end{array}$ \\
\hline Coolant (Pendingin) & Helium (He) \\
\hline $\begin{array}{l}\text { Fraksi volume bahan } \\
\text { bakar }\end{array}$ & $35 \%-65 \%$ \\
\hline Fraksi volume cladding & $10 \%$ \\
\hline Fraksi volume pendingin & $25 \%-55 \%$ \\
\hline Diameter teras aktif & $240 \mathrm{~cm}$ \\
\hline Tinggi teras aktif & $100 \mathrm{~cm}$ \\
\hline $\begin{array}{l}\text { Lebar reflektor arah radial } \\
\text { dan aksial }\end{array}$ & $50 \mathrm{~cm}$ \\
\hline $\begin{array}{l}\text { Lama hidup reaktor } \\
\text { (reactor life) }\end{array}$ & 20 tahun \\
\hline Variasi pengayaan U235 & $5 \%-15 \%$ \\
\hline
\end{tabular}

Pada penelitian ini terdiri dari beberapa step penelitian, yaitu :

1. Pertama analisis faktor multipliasi effektif (k-eff) untuk konfigurasi teras homogen dari persentase pengayaan U235 5\% sampai $15 \%$.

2. Kedua analisis konfigurasi teras heterogen dengan tiga tipe bahan bakar dalam satu teras.

3. Ketiga perbandingan densitas daya dalam reaktor untuk konfigurasi teras homogen dan heterogen, dan

4. Keempat analisis fraksi volume bahan bakar uranium karbida dalam reaktor cepat berpendingin gas.

\section{HASIL DAN PEMBAHASAN}

Perhitungan pertama yang dilakukan dalam penelitian ini adalah melakukan analisis nilai k-eff berdasarkan variasi persentase U235. Gambar 3 merupakan grafik nilai k-eff berdasarkan variasi percentase U235 dari 5\% sampai $15 \%$ dengan menggunakan konfigurasi teras homogen. Dari Gambar 3 dapat dilihat yang paling landai (datar seperti garis lurus) adalah di persentase U235 12\% dengan delta nilai k-eff tertinggi dan terendah 0,00332 atau Copyright (C) 2021 Jurnal Jaring SainTek April 2021 apabila dibuat dalam persentase, maka nilai nya menjadi $0,3 \%$. Maka persentase $12 \%$ ini digunakan sebagai dasar untuk penentuan presentase gabungan tiga tipe presentase bahan bakar dengan menggunakan konfigurasi teras heterogen.

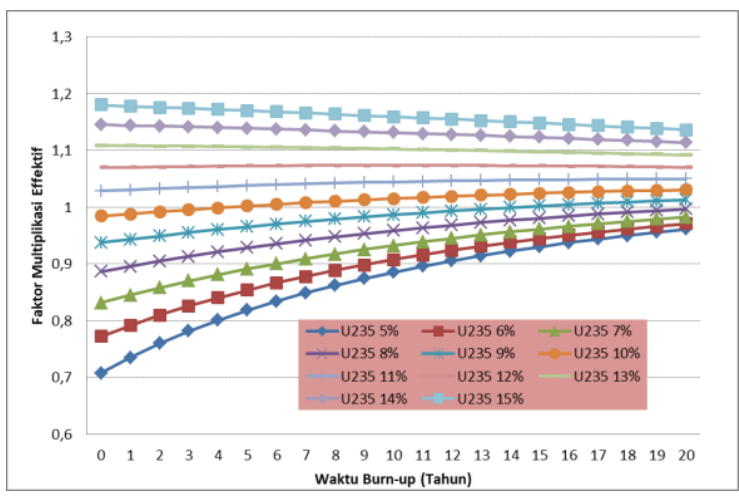

Gambar 3 Grafik nilai k-eff berdasarkan variasi persentase U235 pada konfigurasi teras homogen

Perhitungan selanjutnya yaitu perhitungan konfigurasi teras heterogen dengan tiga tipe presentase bahan bakar. Gambar 4 menunjukkan grafik nilai k-eff dengan menggunakan konfigurasi teras heterogen. Adapun variasi tipe persentase bahan bakarnya ditunjukkan pada Tabel 2. Pada tabel 2 ada lima case yang telah dihitung. Dapat dilihat dari rataratanya, menunjukkan angka $12 \%$, hal ini mengacu pada perhitungan teras homogen. Untuk case 5 dicoba menggunakan rata-rata $13 \%$, tetapidapat dilihat grafiknya pada Gambar 4 untuk menunjukkan bahwa nilai k-eff yang paling landai pada rata-rata $12 \%$.

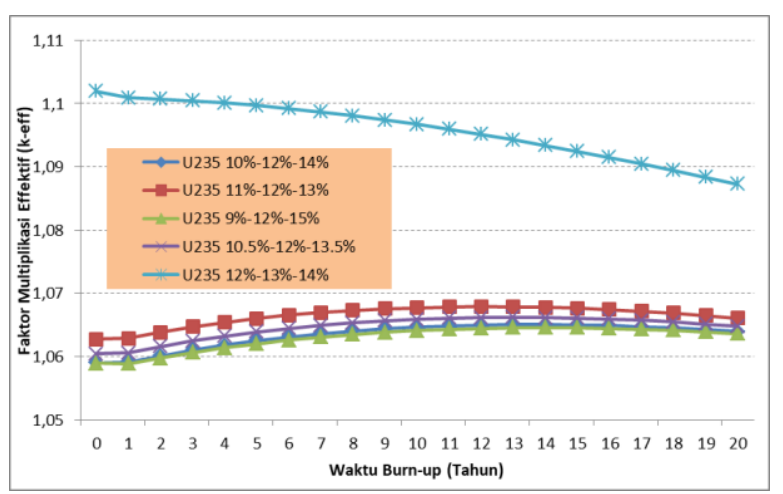

Gambar 4 Grafik nilai k-eff dengan menggunakan konfigurasi teras heterogen

Tabel 2 Variasi persentase bahan bakar

\begin{tabular}{ccccc}
\hline Nama & \multicolumn{3}{c}{ Persentase U235 } & Rata- \\
\cline { 2 - 4 } & Fuel 1 & Fuel 2 & Fuel 3 & rata \\
\hline Case 1 & $10 \%$ & $12 \%$ & $14 \%$ & $12 \%$ \\
\hline
\end{tabular}


Ratna Dewi Syarifah, Nabil Nabhan MH, Zein Hanifah, Iklimatul Karomah, Ahmad Muzaki Mabruri dan Artoto Arkundato

Submitted: 21/10/2020; Revised: 14/12/2020; Accepted: 07/01/2021; Published: 30/04/2021

\begin{tabular}{ccccc}
\hline Case 2 & $11 \%$ & $12 \%$ & $13 \%$ & $12 \%$ \\
\hline Case 3 & $9 \%$ & $12 \%$ & $15 \%$ & $12 \%$ \\
\hline Case 4 & $10,5 \%$ & $12 \%$ & $13,5 \%$ & $12 \%$ \\
\hline Case 5 & $12 \%$ & $13 \%$ & $14 \%$ & $13 \%$ \\
\hline
\end{tabular}

Gambar 5 menunjukkan perbandingan nilai densitas daya menggunakan konfigurasi teras homogen dan heterogen. Dapat dilihat pada gambar bahwa nilai densitas daya dari teras homogen terdapat peaking power di tengah reaktor. Dan ketika menggunakan teras heterogen peaking power di tengah reaktor menjadi flat, hal ini lebih bagus untuk analisis keselamatan reaktor. Maka dari itu untuk perhitungan selanjutnya akan menggunakan teras heterogen. Perbandingan nilai densitas daya rata-rata dan daya maksimumnya dapat dilihat pada Tabel 3.

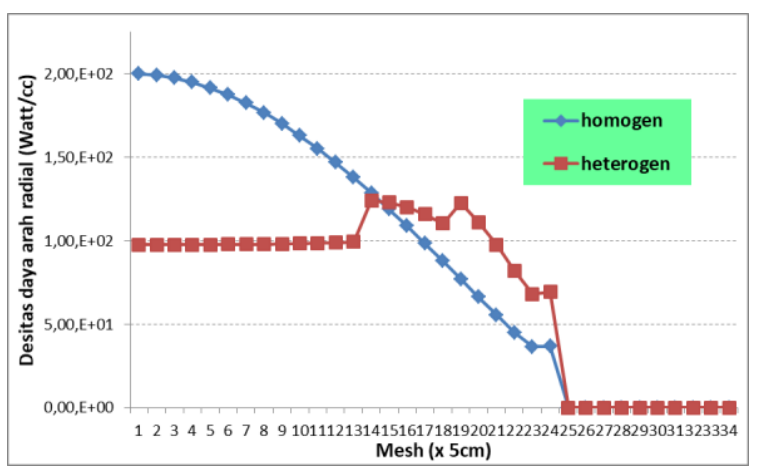

Gambar 5 Grafik perbandingan nilai densitas daya menggunakan konfigurasi teras homogen dan heterogeny

Tabel 3 Perbandingan nilai densitas daya ratarata konfigurasi teras homogen dan heterogen

\begin{tabular}{cccc}
\hline Nama & $\begin{array}{c}\text { Konfigurasi } \\
\text { teras }\end{array}$ & $\begin{array}{c}\text { Densitas } \\
\text { daya } \\
\text { rata- } \\
\text { rata } \\
\text { (watt/cc) }\end{array}$ & $\begin{array}{c}\text { Densitas } \\
\text { daya } \\
\text { maksimum } \\
\text { (watt/cc) }\end{array}$ \\
\hline $\begin{array}{c}\text { U235 } \\
12 \%\end{array}$ & Homogen & 87,9 & 175 \\
\hline $\begin{array}{c}\text { Case } \\
3\end{array}$ & Heterogen & 78,6 & 97 \\
\hline
\end{tabular}

Gambar 6 menunjukkan grafik nilai k-eff dengan variasi bahan bakar dari 35\% sampai 65\%. Dari Gambar 6 tersebut dapat dilihat bahwa semakin bertambah volume fraksi bahan bakar maka akan menambah nilai k-eff. Penambahan nilai k-eff akan semakin berkurang seiring dengan penambahan volume fraksi bahan bakar. Dari volume fraksi bahan bakar $35 \%$ menuju $40 \%$ mengalami penambahan nilai k-eff yang signikan dibandingkan dengan penambahan dari volume $60 \%$ menuju $65 \%$. Dari gambar 6 dapat dilihat bahwa nilai $\mathrm{k}$-eff $=1$ yang mendekati nilai kritis pada reaktor, yaitu pada volume bahan bakar 50\%. Untuk itu pada Gambar 7 menjelaskan lebih detail mengenai penambahan volume fraksi bahan bakar dari 45\% sampai 50\% untuk mencari nilai k-eff dengan excess reactivity terendah (kurang dari 1\%).

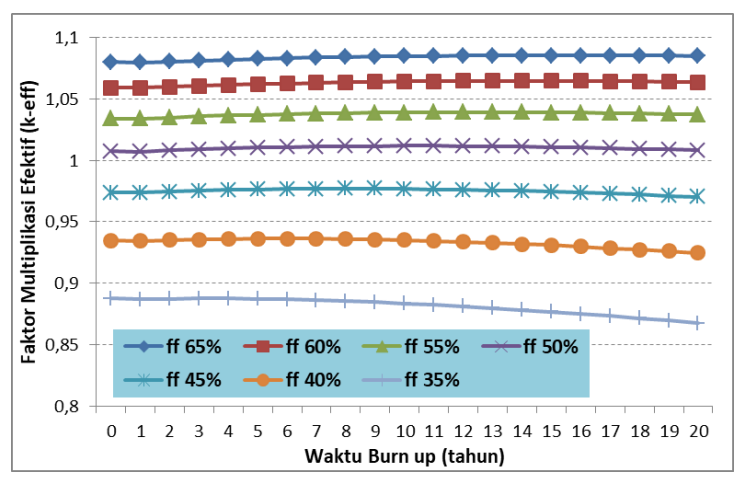

Gambar 6 Grafik nilai k-eff dengan variasi volume bahan bakar dari $35 \%$ sampai $65 \%$

Pada Gambar 7 ditunjukkan grafik nilai k-eff untuk variasi volume bahan bakar dari 45\% sampai 50\%. Dari Gambar 7 dapat dilihat bahwa pada fraksi volume $45 \%$ sampai $48 \%$, memiliki nilai k-eff dibawah 1 (k-eff $<1$ ), artinya reaktor dalam keadaan subkritis. Pada penelitian ini kita mencari nilai k-eff lebih dari 1 (k-eff $>1$ ) dengan excess reactivity kurang dari $1 \%$. Dalam grafik tersebut dapat dilihat bahwa fraksi volume $49 \%$ dan $50 \%$ memiliki nilai 
excess reactivity kurang dari $1 \%$. Namun pada fraksi volume $50 \%$, memiliki nilaik-eff lebih dari 1, maka dari itu dipilihlah fraksi volume 49\% sebagai hasil optimasi analisis fraksi volume bahan bakar.

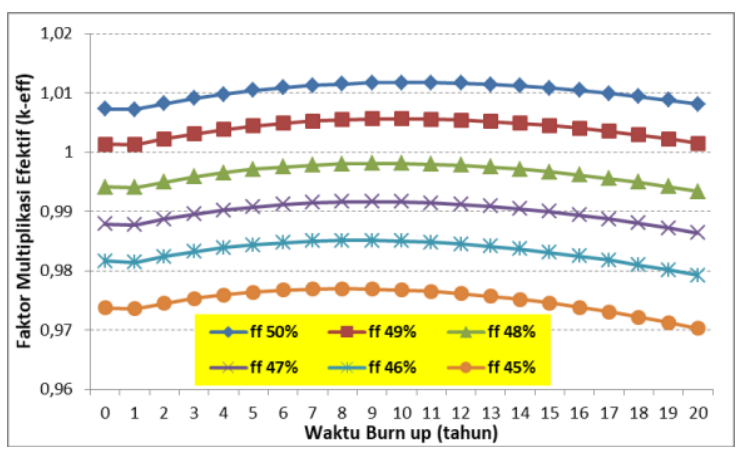

Gambar 7 Grafik nilai k-eff untuk variasi volume bahan bakar dari $45 \%$ sampai $50 \%$

Pada Gambar 7 ditunjukkan hasil optimasi analisis variasi fraksi volume bahan bakar. Dipilihlah fraksi volume $49 \%$ sebagai optimasi dengan nilai excess reactivity $0,435 \%$. Pada penelitian ini hanya meneliti sampai pada analisis variasi volume bahan bakar dengan bahan bahar uranium karbida. Untuk itu diperlukan penelitian lebih lanjut mengenai analisis bentuk teras reaktor, penambahan aktinida minor dalam bahan bakar, dan juga analisis variasi daya reaktor.

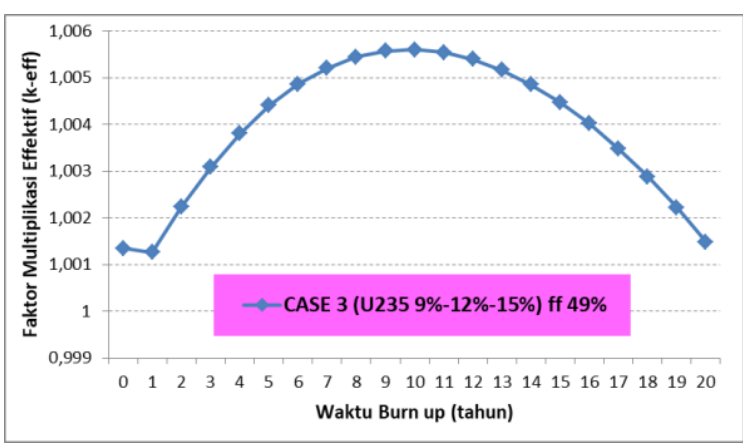

Gambar 8 Grafik optimasi nilai k-eff untuk fraksi volume bahan bakar

\section{KESIMPULAN DAN SARAN}

Perhitungan analisis fraksi volume bahan bakar dengan menggunakan bahan bakar uranium karbida untuk reaktor cepat berpendingin gas telah berhasil dilakukan dengan hasil optimasi fraksi volume bahan bakar $49 \%$ dengan konfigurasi teras heterogen tiga tipe persentase bahan bakar, untuk Fuel $1=$ 9\%, Fuel $2=12 \%$ dan Fuel $3=15 \%$ dengan reaktor berbentuk silinder, memiliki diameter teras $240 \mathrm{~cm}$ dan tinggi teras $100 \mathrm{~cm}$.
Penelitian ini merupakan studi awal penggunaan bahan bakar uranium karbida pada reaktor cepat berpendingin gas, untuk itu diperlukan penelitian lanjut pada penelitian ini agar hasil optimasi yang kita dapatkan lebih sempurna dan lebih teliti. Adapun penelitian lanjutan dari penelitian ini adalah penelitian mengenai bentuk teras reaktor, penambahan aktinida minor dalam bahan bakar, penambahan plutonium untuk limbah nuklir serta analisis variasi daya reaktor.

\section{UCAPAN TERIMA KASIH}

Penelitian ini dibiayai oleh Universitas Jember melalui Hibah Keris tahun 2020.

\section{DAFTAR PUSTAKA}

GIF. (2014). Generation IV International Forum Research Technology Roadmap Update for Generation IV Nuclear Energy System. GIV-IV (The Generation IV International Forum) and the OECD Nuclear Energy Agency

Anzieu (2009) Anzieu, P., Stainsby, R. dan Mikityuk, K (2009): Gas Cooled Fast Reactor (GFR) Overview and Perspective, GIF Symposium, Paris, France, 127-134

GIF. (2002) A technology Roadmap for Generation IV Nuclear Energy System. GIF-IV (The Generation IV International Forum) and U.S DOE Nuclear Energy Research Advisory Committee

GIF. (2014). Generation IV International Forum Research Technology Roadmap Update for Generation IV Nuclear Energy System. GIV-IV (The Generation IV International Forum) and the OECD Nuclear Energy Agency

Okumura, K., (2002): SRAC2002: The comprehensive Neutronic Calculation Code System. Japan Atomic Energy Agency (JAEA), Japan

Syarifah, R. D., Yulianto Y., Su'ud Z., Basar K, \& Irwanto D. (2016). Neutronic Analysis of Thorium Nitride (Th, U233)N Fuel for 500MWth Gas Cooled Fast Reactor (GFR) Long life without Refueling, Key Engineering Materials, ISSN: 1662-9795, Vol. 733, pp 47-50, doi:10.4028/www.scientific.net/KEM.73 3.47

Syarifah, R. D., Su'ud Z., Basar K, \& Irwanto D. (2016). Design Study of 200MWth Gas 
Ratna Dewi Syarifah, Nabil Nabhan MH, Zein Hanifah, Iklimatul Karomah, Ahmad Muzaki Mabruri dan Artoto Arkundato

Submitted: 21/10/2020; Revised: 14/12/2020; Accepted: 07/01/2021; Published: 30/04/2021

Cooled Fast Reactor with Nitride (UNPuN) Fuel Long Life without Refueling, MATEC Web of Conferences, 2016, 82, 03008 , DOI: 10.1051/matecconf/20168203008

Syarifah, R. D., Su'ud Z., Basar K, \& Irwanto D. (2016). The Prospect of Uranium Nitride (UN-PuN) Fuel for 25-100MWe Gas Cooled Fast Reactor Long Life without Refuelling. Journal of Physics: Conference Series 776 (2016) 012103, DOI:10.1088/1742-6596/776/ 1/012103

Syarifah, R. D., Su'ud Z., Basar K, Irwanto D., Pattipawaej S. C. \& Ilham M. (2017). Comparison of Uranium and Thorium Nitride Fuel for 500MWth Gas Cooled Fast Reactor (GFR) Longlife without Refueling, International Journal of Energy Research, Special Issue Paper, page 1-7, doi:10.1002/er.3923

Syarifah, R. D., Su'ud Z., Basar K, \& Irwanto D. (2017). Fuel Fraction Analysis of 500 MWth Gas Cooled Fast Reactor with Nitride (UN-PuN) Fuel without Refueling, IOP Conf. Series: Journal of Physics: Conf. Series 799 (2017) 012022, doi:10.1088/1742-6596/799/1/012022

Syarifah, R. D., Su'ud Z., Basar, K, \& Irwanto, D. (2017). Neutronic Analysis of UN-PuN Fuel use FI-ITB-CHI Code for 500MWth
GFR Long Life Without Refueling. IOP Conf. Series: Journal of Physics: Conf. Series 1090 (2018) 012033, doi :10.1088/1742-6596/1090/1/012033

Syarifah, R. D., Su'ud Z., Basar, K, \& Irwanto, D. (2020). Actinide Minor Addition on Uranium Plutonium Nitride Fuel for Modular Gas Cooled Fast Reactor. Journal of Physics: Conference Series 1493 (2020) 012020. doi:10.1088/17426596/1493/1/012020

Syarifah, R. D., Arkundato, A., Su'ud Z. \& Irwanto, D. (2020). Neutronic analysis of comparation UN-PuN fuel and ThN fuel for 300MWth Gas Cooled Fast Reactor long life without refueling. IOP Conf. Series: Journal of Physics: Conf. Series 1436 (2020) 012132, doi:10.1088/17426596/1436/1/012132

Fareha, M.A., Syarifah, R. D., Su'ud Z \& Kurniasih N. (2018). Design Study of 600 MWt Long Life Modular Gas Cooled Fast Reactors. IOP Conf. Series: Journal of Physics: Conf. Series 1090 (2018) 012021. doi :10.1088/1742-6596/1090/ $1 / 012021$ 